\title{
PET and SPECT imaging of tumor micro-environment: a systematic review of the last 20 years
}

Valeria Stati, Chiara Lauri, Michela Varani, Martina Conserva, Alberto Signore

Nuclear Medicine Unit, S. Andrea University Hospital, Department of Medical-Surgical Sciences and of Translational Medicine, Sapienza University of Rome, Italy.

\section{Corresponding author:}

Alberto Signore MD, PhD

Nuclear Medicine Unit,

S. Andrea University Hospital, Via di Grottarossa 1035

00189 Rome, Italy

alberto.signore@uniroma1.it 


\begin{abstract}
Background: Molecular nuclear medicine, due to hybrid imaging camera systems and new tailored radiopharmaceuticals, has been gained a clinical relevance for diagnosis, therapy and follow-up of solid tumors. Despite numerous literature studies, many new radiopharmaceuticals for imaging tumor microenvironment, have not yet been used, routinely, in oncological clinical practice to monitor treatments. This is due to poor comparability of published studies, due to poor design and methodology, heterogeneous population and prevalence of preclinical studies.

Methods: In this systematic review, we described the use of radiopharmaceuticals for evaluation of tumor treatment response by targeting microenvironment. We reviewed studies published from 2000 to 2020, to provide an updated status of research in this topic.

Results: There is a growing role of radiopharmaceuticals and nuclear medicine imaging techniques in the management of cancer treatments, especially immunotherapy. Of the 24 papers included, 16 were preclinical studies.

Conclusions: New radiopharmaceuticals could have an excellent impact in molecular imaging, leading to better diagnosis and important clinical information for therapy decision making and follow-up of cancer treatments in different solid tumors. Recently developed radiopharmaceuticals may provide great advantage to improve personalized medicine for patients with a great costeffectiveness ratio.
\end{abstract}

\title{
Keywords
}

microenvironment, radiopharmaceuticals, treatment response, personalised medicine 


\section{Introduction}

Nuclear Medicine (NM) offers the possibility to identify tissue functional changes that might precede the onset of anatomical alteration detectable with traditional radiologic techniques. Therefore, NM imaging could be helpful for early detection and for guiding the diagnostic and therapeutic approach of different disease, especially in oncological setting [1]. Recently, NM evolved in molecular NM because it can provide not only diagnosis but also individualize different cell types and molecules involved in the carcinogenesis process. Molecular NM has become possible due to new highly sensitive hybrid imaging cameras, such as single photon emission tomography/ computed tomography (SPECT/CT), positron emission tomography (PET)/CT, and PET/Magnetic Resonance Imaging (MRI), and to new radiopharmaceuticals tailored to specific molecular targets, relevant for therapy decision making and follow-up of cancer patients. Different radiopharmaceuticals, exploring different aspects of complex mechanisms involved in cancer development and targeting tumor microenvironment (TME) components can be used [2-3].

Indeed, TME has gained an important role in tailored cancer therapies [4]. We know that tumor growth requires a complex interaction between host and cancer cells [5]. For example, fibroblasts, cellular components of TME, play an important role promoting tumor and vessel growth. They also have both stimulatory and inhibitory effects on T-lymphocytes [6]. Tumor associated macrophages are also important in TME. They migrate into cancer maturating in M1, with an anti-tumor effect through the production of pro-inflammatory cytokines, or M2 phenotype with a pro-tumor effect through the production of growth factors.

In this complex scenario, NM could contribute to clarify the role of TME by imaging its components such as chemokine receptors, immune cells, stromal antigens, vascular factors and many others.

Several radiopharmaceuticals have been developed and tested in preclinical and clinical studies. Indeed, they could be used to better understand the cancer-related processes such as cell proliferation, angiogenesis, tumour hypoxia, altered metabolism and gene expression, evasion of immune system, inactivation of apoptosis pathways. These different carcinogenesis pathways could be used as biomarkers to provide relevant information to cancer diagnosis and personalized treatment through functional tumour imaging.

Interleukin-2 (IL2) has been largely investigated for imaging TME [7]. It can be used, for SPECT and PET studies, as a marker of activated T lymphocytes in several solid tumours, including renal cell carcinoma [8], melanoma [9], squamous cell carcinomas of head and neck [10], showing an optimal biodistribution.

One of the pathways investigated, especially in non-small-cell lung cancer (NSCLC), is programmed death 1 (PD-1) and the programmed death ligand 1 (PDL-1) [11]. Preliminary clinical trials provided encouraging results on the use of monoclonal antibodies (MoAbs) directed against these molecules and several efforts are directed to the development of radiopharmaceuticals in order to map the expression of the PD-1/PDL-1 pathways and to predict the response to treatment.

Most of these cytokines and MoAbs are now available for therapeutic purposes and in some cases also as kit for easy radiolabelling. Indeed, the growing use of radiolabelled MoAbs in cancer patients for both diagnostic and follow-up purposes, is evident from the increasing amount of literature on immuno-SPECT and immune-PET imaging.

The aim of this systematic review is to provide updated evidence on this topic, highlighting strengths and limitations among studies on radiopharmaceuticals for imaging TME in the era of personalized medicine. 


\section{Materials and Methods}

We conducted this systematic review in accordance with the guideline of Preferred Reporting Items for Systematic Reviews and Meta-Analyses Protocols (PRISMA) 2015 statement [12].

Two authors separately performed the literature search and individualized the selected articles. Discrepancies in the two authors' inclusions were resolved by consensus. We restricted our research only to papers published in English language. We used the PICO (population, intervention, comparison and outcome) framework to improve the literature searching for the clinical questions of our study.

We identified published articles on PET and SPECT imaging and TME from the Medline database through PubMed, using the string "(("Immuno"[All Fields] AND ("SPECT"[All Fields] OR "tomography, emission computed, single photon"[MeSH Terms])) OR ("radionuclide imaging"[MeSH Terms] OR ("radionuclide"[All Fields] AND "imaging"[All Fields]) OR ("nuclear"[All Fields] AND "medicine"[All Fields]) OR "nuclear medicine"[All Fields] OR "nuclear medicine"[MeSH Terms] OR ("nuclear"[All Fields] AND "medicine"[All Fields])) OR ("radiopharmaceutic"[All Fields] OR "radiopharmaceuticals"[All Fields] OR "radiopharmaceuticals"[Pharmacological Action] OR "radiopharmaceuticals"[MeSH Terms] OR "radiopharmaceuticals"[All Fields] OR "radiopharmaceutical"[All Fields] OR "radiopharmaceutics"[All Fields])) AND ("tumor microenvironment"[MeSH Terms] OR ("tumor"[All Fields] AND "microenvironment"[All Fields]) OR "tumor microenvironment"[All Fields]))". A similar strategy was used for SCOPUS and EMBASE search. Other reports were extracted by checking the reference lists of the retrieved articles. We included original clinical and preclinical studies, excluding abstracts or posters, commentaries and letters to editors.

For each included paper, we described characteristics of the study, such as first author, year, country of publication and population characteristics. We evaluated different TME target types, such as tumor cells, peripheral blood mononuclear cells (PBMCs) and tumor-infiltrating lymphocytes (TILs). For each TME type, we studied the radionuclide or the antibody-drug conjugates used, the clinical or preclinical setting, the size of population. Finally, we evaluated the information in terms of recognition of different TME targets and the ability of different radiopharmaceuticals to predict treatment response.

\section{Results}

One thousand seven hundred and forty articles have been identified and 950 of them remained after exclusion of duplicates. Among them, we evaluated 410 articles and 25 were finally selected for inclusion. Two more articles were rejected and 23 papers were included in the review, 16 of which, where preclinical studies (Figure 1).

Study characteristics from the 23 included papers are reported in Table 1.

The selected reports were published from 2004 to 2020 and were mainly conducted in the Netherlands [13-16, 17-19] and in USA [20-27]. Of the other countries involved, there were other European countries [28-31], China [32-33], Canada [34] and Japan [35].

In literature, there are few data about the use of molecular imaging to detect TME targets, although several trials are still ongoing. We analyzed the status of completed and recruiting trials involving our topic, summarizing the principal retrieved studies, according to data of the "ClinicalTrials.Gov" website (Table 2).

New developed radiopharmaceuticals for imaging different components of TME are summarized in Table 3. 


\section{Tumor cells imaging}

Evaluating tumor cells, Carbonic anhydrase IX (CAIX) was found to be an excellent target for imaging in clear cell renal cell carcinoma (ccRCC). Indeed, CAIX is a specific antigen that is highly expressed in ccRCC. For this reason, the use of immunoSPECT imaging with the indium-111 ( $\left.{ }^{111} \mathrm{In}\right)$-labeled antiCAIX antibody girentuximab could have relevant implications in the diagnosis and follow-up of cCRCC patients. In literature there are different studies on humans and murine models that confirm the utility of this target in management of ccRCC $[13-14,16,30]$.

The three clinical trials $[13-14,16]$, conducted in the Netherlands, confirmed the ability of ${ }^{111} \mathrm{In}$ girentuximab to detect ccRCC lesions, also after cryoablation procedures. These nuclear imaging techniques could early detect residual or recurrent disease with improvement of patients' survival. In particular, Muselaers $\mathrm{CH}$ et al, evaluated the combination of sorafenib, a tyrosine kinase inhibitor (TKI), and girentuximab based therapy. 15 patients with cCRCC were enrolled and underwent ${ }^{111} \mathrm{In}$ girentuximab imaging. Ten patients were treated with sorafenib in a neoadjuvant setting. After surgery, distribution of ${ }^{111}$ In-girentuximab was determined in the specimens of tissue kidney, instead the CAIX expression was evaluated with immunohistochemistry (IHC). The authors demonstrated that sorafenib reduced the ${ }^{111}$ In-girentuximab uptake in in ccRCC lesions. These results showed that TKI could interfere with the efficacy of antibody-mediated treatment [16].

A preclinical study in head and neck cancer murine models demonstrated that ${ }^{111}$ In-girentuximab was a promising radiopharmaceutical for imaging of hypoxia related CAIX expression, suggesting the need for future research in CAIX imaging for other solid tumors [15].

Girentuximab has been used in preclinical trials both pre- and post-labelling with ${ }^{177} \mathrm{Lu}$. Basaco T. et al., performed in vitro and in vivo experiments with ${ }^{177}$ Lu-girentuximab, demonstrating a lower tumor uptake associated with necrotic tumor areas and heterogeneous CAIX expression [28].

Another target, overexpressed in prostate cancer, is represented by prostate-specific membrane antigen (PSMA). Lütje S. et al., evaluated the microSPECT imaging studies with ${ }^{111} \ln$-D2B IgG, ${ }^{111} \mathrm{In}$ capromab pendetide, 111/n-D2B F(ab')2 and 111/n-D2B Fab fragments in xenografts with PSMA expression, demonstrating that this radiopharmaceutical could be considered as a good target of PSMA-expressing prostate cancer xenografts.

The efficacy of new oncological drugs with immune checkpoint inhibitors (ICls), is recently gaining a great interest. ICls are antibodies that block PD-1 or PD-L1 or cytotoxic T-lymphocyte-associated antigen 4 (CTLA4) checkpoints. In this setting molecular NM imaging is able to provide more accurate molecular information and it might play an important role in predicting the efficacy of immunotherapy [36-37].

In particular, TME nuclear imaging has achieved unexpected progress thanks to the introduction of several PDL1-targeted radiopharmaceuticals, including ${ }^{111}$ In-PD-L1.3.1 [18], ${ }^{89}$ Zr-DFO-PD-L1 MoAb [20], and ${ }^{68} \mathrm{Ga}-\mathrm{DOTA}-\mathrm{Nb} 109$ [32]. These radiopharmaceuticals were tested in several preclinical studies [38] in murine models of different solid tumors, such as breast, gastric, lung cancer and melanoma.

Molecular NM could provide a quantitative imaging assessment of PD-L1 tumor expression, identifying patients with low or high PD-L1 expression levels. This information is an important predictive factor for evaluation of treatment response and could become an easily imaging biomarker for response monitoring for ICls [18, 32].

Recently, Avelumab, an anti-PD-L1 human antibody, was labelled with ${ }^{89} \mathrm{Zr}$ to image immune cell status in bearing mice. In vitro and in vivo studies demonstrated an increasing tissue uptake in PDL1 positive tumors and with escalation dose of immunotherapy. The results encouraged further PD-L1 immuno-nuclear imaging studies [20].

Similarly, immuno-PET could be used in the management of target therapies $[19,30]$ in several solid 
tumors, such as head and neck carcinomas. In fact, Hoeben et al. demonstrated, in bearing mice, the possibility to select patients to epidermal growth factor receptor (EGFR) target therapy with noninvasive nuclear imaging using ${ }^{111}$ In-cetuximab [19].

A similar approach could be employed to identify other proteins expressed by tumor cells, such as Insulin growth factor receptor (IGF-1R) and B7-H3. High affinity to IGF-1R has been demonstrated by ${ }^{111} \mathrm{In}$ - and $225 \mathrm{Ac}$-Cixutumumab in triple negative breast cancer (TNBC) models [34].

B7-H3 tumor cell protein expression, was also evaluated in colon cancer by using DS-5573a, an antiB7-H3 MoAb labeled with ${ }^{89} \mathrm{Zr}$. A preclinical study confirmed the capacity of ${ }^{89} \mathrm{Zr}-\mathrm{DS}-5573 \mathrm{a}$ to target B7-H3-expressing tumors [21].

\section{PBMCs imaging}

Noninvasive immuno-PET had also the ability to find immunotherapy-induced alterations in PBMCs, tracking of endogenous CD8+ T cells in melanoma models. Thus, ${ }^{89} \mathrm{Zr}$-anti-CD8 could be useful to evaluate therapeutic responses of ICls [22].

\section{TILS imaging}

Another approach to image the TME, is by targeting TILS. Several radiopharmaceuticals and approaches have been tested for this purpose, being radiolabelled IL2, the most promising.

This radiopharmaceutical interacts with IL2 receptors (IL2R) expressed on activated T lymphocytes thus allowing an in vivo evaluation of these cells' subset in several autoimmune and oncologic diseases. ${ }^{99 m}$ Tc-IL2 was tested for imaging melanoma, demonstrating its ability to evaluate TILs changes and therapeutic response of ICls [23]. These findings were demonstrated in an Italian study in which 21 melanoma patients underwent $99 \mathrm{mTC}$-IL2 scintigraphy.

Scintigraphy, using radiolabeled IL2, detected the activated TILs expressing IL2R in vivo, providing an important prognostic information to better select melanoma patients who might benefit from IL2 immunotherapy [31].

Moreover, ${ }^{123} \mathrm{I}-\mathrm{IL}-2$ was employed in head and neck and renal carcinomas, detecting the response to cytokine treatments [29-30].

Furthermore, molecular imaging could evaluate the efficacy of the anti-CTLA-4 immunotherapies. In this setting, ${ }^{64} \mathrm{Cu}$-DOTA-anti-CTLA-4 was developed to evaluate CTLA-4 expression in bearing mice colon cancer [35]. Immuno-PET was also evaluated in NSCLC mouse models with the similar findings [24].

Finally, some preclinical studies showed specific accumulation of radiolabelled PD-1 targeting antibodies such as pembrolizumab and nivolumab. ${ }^{89} \mathrm{Zr}$-pembrolizumab [25] and ${ }^{64} \mathrm{Cu}$ pembrolizumab [26] were tested in melanoma models, and predicted the effectiveness of pembrolizumab therapy. Instead, ${ }^{89} \mathrm{Zr}$-labeled nivolumab demonstrated to be useful to identify Tcells expressing PD-1 in murine models of lung cancer.

The evaluation of different TME targets, through specific radiotracers, could guide in the future the oncological management of cancer patients.

\section{Discussion and conclusion}

Medical research has progressively adopted new strategies to really understand the biological basis of cancer disease. To this aim, in the last decades several efforts have been made in molecular NM for better identifying which target molecules play a crucial role in the pathogenesis and progression of cancer and for the development of specific and tailored therapies. Indeed, by assessing TME targets with molecular NM techniques, it will be possible to choose the most tailored therapy for 
cancer patients, avoiding unnecessary or useless drugs. Since new oncological treatments, especially MoAbs, are very expensive, molecular imaging techniques could have an important costeffectiveness role by helping in the therapy decision making.

In this systematic review, we summarize new emerging radiopharmaceuticals for imaging in different solid tumors (Table 1) and we present some of clinical and preclinical trials that have been conducted worldwide (Table 2). We also provide an overview of improvements in molecular NM imaging technologies, which have the potential to transform NM moving forward.

More studies with more representative sample size and in human setting are necessary to better investigate new and more specific target molecules, new radiopharmaceuticals and new tailored therapies with an effective clinical impact for a personalized medicine. For this goal, non-invasive NM imaging could be routinely used in oncological clinical practice.

\section{Author contribution}

Conceptualization: AS, VS; writing-original draft preparation: VS; writing-review and editing: CL; supervision: AS; project administration: $A S$; funding acquisition: AS; extraction and curation of data. VS, MV, MC; analysis of data: VS, CL.

All authors have reviewed the manuscript and agreed to their individual contributions prior to submission.

\section{Institutional Review Board Statement}

Not applicable.

\section{Informed Consent Statement}

Not applicable.

\section{Data Availability Statement}

Not applicable.

\section{Conflicts of Interest}

The authors declare no conflict of interest. 


\section{Legend to figures}

Figure 1: PRISMA 2009 Flow Diagram
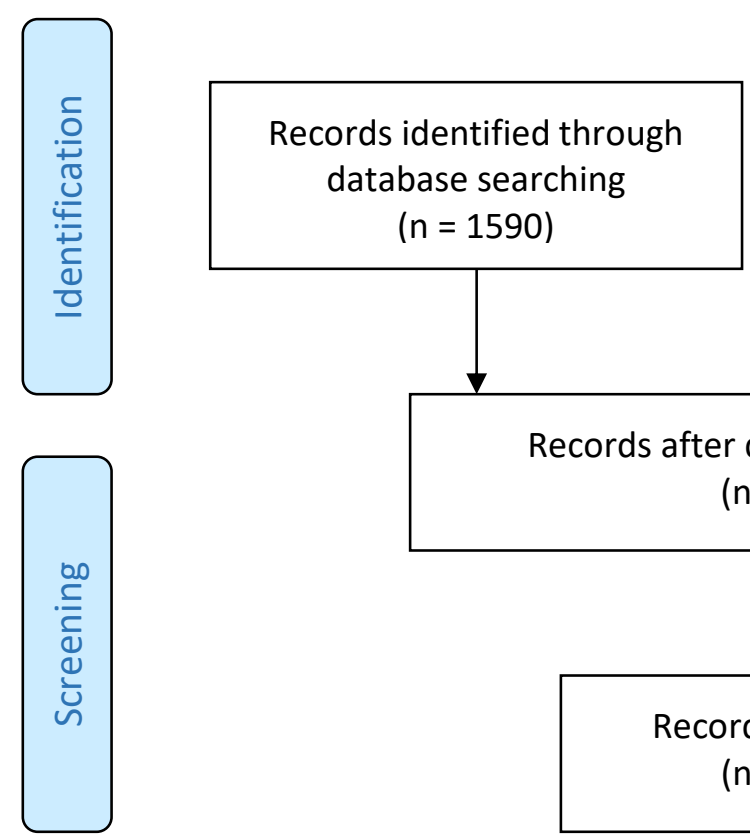

Records after duplicates removed

$$
(n=950)
$$
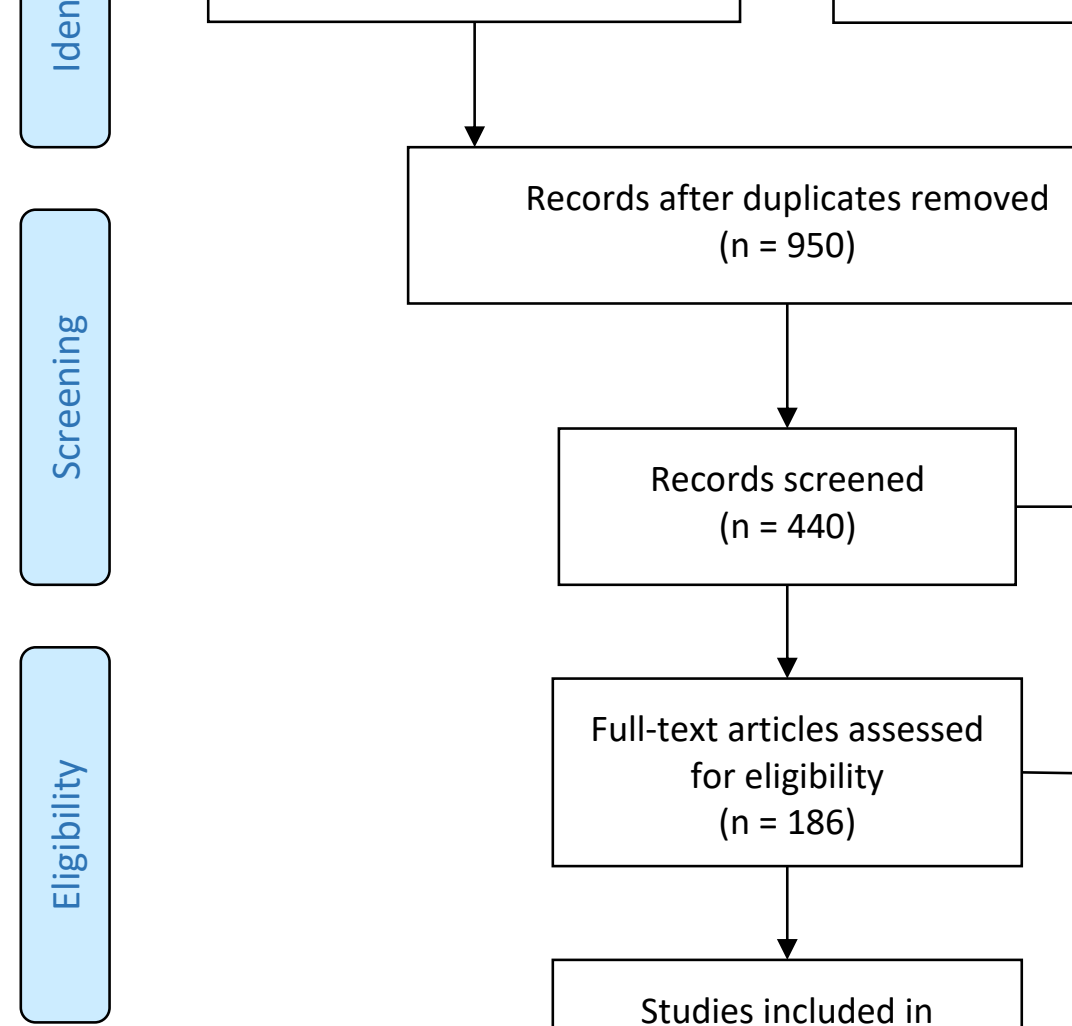

Additional records identified through other sources

$$
(n=150)
$$

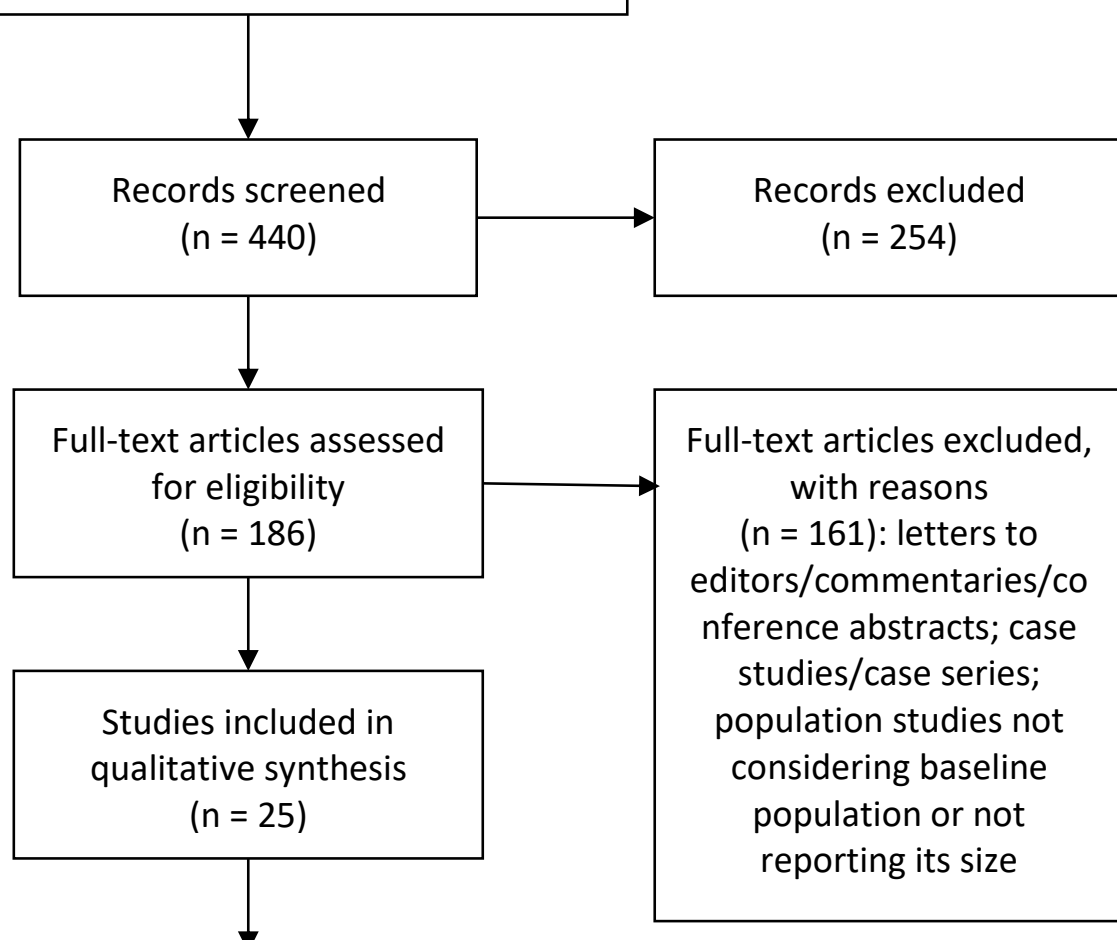

Studies included in quantitative synthesis

(systematic review)

$$
(n=23)
$$


Table 1. Characteristics of examined studies

\begin{tabular}{|c|c|c|c|c|c|}
\hline Author & Country & Radiopharmaceutical & Cancer & $\begin{array}{c}\text { Type } \\
(\mathrm{H}, \mathrm{C}, \mathrm{O})\end{array}$ & Phase \\
\hline $\begin{array}{c}\text { Muselaers Chet et } \\
\text { al, } 2013 \text { [13] }\end{array}$ & The Netherlands & ${ }^{111}$ In-girentuximab & $\begin{array}{c}\text { Clear cell renal } \\
\text { carcinoma }\end{array}$ & $\mathrm{C}$ & Not applicable \\
\hline $\begin{array}{l}\text { van Oostenbrugge } \\
\text { TJ et al, } 2019 \text { [14] }\end{array}$ & The Netherlands & ${ }^{111}$ In-girentuximab & $\begin{array}{l}\text { Clear cell renal } \\
\text { carcinoma }\end{array}$ & C & $\begin{array}{c}\text { Not applicable } \\
\text { (Prospective study) }\end{array}$ \\
\hline $\begin{array}{l}\text { Huizing FJ et al, } \\
2017 \text { [15] }\end{array}$ & The Netherlands & ${ }^{111}$ In-girentuximab & $\begin{array}{l}\text { Head\&Neck } \\
\text { carcinoma }\end{array}$ & C & $\begin{array}{c}\text { Not applicable } \\
\text { (Preclinical study) }\end{array}$ \\
\hline $\begin{array}{c}\text { Muselaers CH et al, } \\
2014[16]\end{array}$ & The Netherlands & ${ }^{111}$ In-girentuximab & $\begin{array}{l}\text { Clear cell renal } \\
\text { carcinoma }\end{array}$ & $\mathrm{H}$ & Not applicable \\
\hline $\begin{array}{c}\text { Basaco T et al, } 2018 \\
{[28]}\end{array}$ & Germany & ${ }^{177}$ Lu-girentuximab & $\begin{array}{c}\text { Renal } \\
\text { carcinoma }\end{array}$ & C & $\begin{array}{c}\text { Not applicable } \\
\text { (Preclinical study) }\end{array}$ \\
\hline $\begin{array}{c}\text { Lütje S et al, } 2014 \\
\text { [17] }\end{array}$ & The Netherlands & $\begin{array}{c}{ }^{111} \text { In-labeled D2B IgG- } \\
\text { DTPA, F(ab')2-DTPA, } \\
\text { Fab-DTPA, and } \\
\text { capromab-DTPA }\end{array}$ & Prostate cancer & $\mathrm{C}$ & $\begin{array}{l}\text { Not applicable } \\
\text { (Preclinical study) }\end{array}$ \\
\hline $\begin{array}{c}\text { Heskamp S et al, } \\
2015 \text { [18] }\end{array}$ & The Netherlands & ${ }^{111}$ In-PD-L1.3.1 & Breast cancer & $\mathrm{C}$ & $\begin{array}{c}\text { Not applicable } \\
\text { (Preclinical study) }\end{array}$ \\
\hline $\begin{array}{c}\text { Jagoda, E.M et al, } \\
2019[20]\end{array}$ & USA & $\begin{array}{c}{ }^{89} \mathrm{Zr}-\mathrm{DFO}-\mathrm{PD}-\mathrm{L} 1 \\
\text { MoAb }\end{array}$ & $\begin{array}{l}\text { Breast, gastric, } \\
\text { lung cancer }\end{array}$ & C & $\begin{array}{l}\text { Not applicable } \\
\text { (Preclinical study) }\end{array}$ \\
\hline Lv G et al, 2020 [32] & China & ${ }^{68} \mathrm{Ga}-\mathrm{DOTA}-\mathrm{Nb} 109$ & Melanoma & C & $\begin{array}{c}\text { Not applicable } \\
\text { (Preclinical study) }\end{array}$ \\
\hline $\begin{array}{l}\text { Hoeben BA et al, } \\
2011 \text { [19] }\end{array}$ & The Netherlands & ${ }^{111}$ In-cetuximab & $\begin{array}{l}\text { Head\&Neck } \\
\text { squamous cell } \\
\text { carcinoma }\end{array}$ & $\mathrm{C}$ & $\begin{array}{l}\text { Not applicable } \\
\text { (Preclinical study) }\end{array}$ \\
\hline $\begin{array}{c}\text { Liu X et al, } 2017 \\
\text { [33] }\end{array}$ & China & $125 \mid-4 G 1$ & Glioblastoma & $\mathrm{C}$ & $\begin{array}{c}\text { Not applicable } \\
\text { (Preclinical study) }\end{array}$ \\
\hline $\begin{array}{c}\text { Solomon VR et al, } \\
2019 \text { [34] }\end{array}$ & Canada & $\begin{array}{c}{ }^{111} \text { In- and } \\
{ }^{225} \text { Ac-Cixutumumab }\end{array}$ & $\begin{array}{l}\text { Triple negative } \\
\text { breast cancer }\end{array}$ & $\mathrm{C}$ & $\begin{array}{c}\text { Not applicable } \\
\text { (Preclinical study) }\end{array}$ \\
\hline $\begin{array}{l}\text { Burvenich IJG et al, } \\
2018 \text { [21] }\end{array}$ & USA & ${ }^{89} \mathrm{Zr}-\mathrm{DS}-5573 a$ & $\begin{array}{l}\text { Breast, colon } \\
\text { cancer }\end{array}$ & $\mathrm{C}$ & $\begin{array}{c}\text { Not applicable } \\
\text { (Preclinical study) }\end{array}$ \\
\hline $\begin{array}{c}\text { Tavaré R et al, } 2016 \\
\text { [22] }\end{array}$ & USA & ${ }^{89} \mathrm{Zr}$-anti-CD8 & Melanoma & $\mathrm{C}$ & $\begin{array}{c}\text { Not Applicable } \\
\text { (Preclinical study) }\end{array}$ \\
\hline $\begin{array}{l}\text { Loose D et al, } 2008 \\
\text { [29] }\end{array}$ & Belgium & ${ }^{123} \mathrm{I}-\mathrm{IL}-2$ & $\begin{array}{l}\text { Head\&Neck } \\
\text { carcinoma }\end{array}$ & $\mathrm{O}$ & $\begin{array}{c}\text { Not applicable } \\
\text { (Prospective study) }\end{array}$ \\
\hline $\begin{array}{c}\text { Markovic SN et al, } \\
2008[23]\end{array}$ & USA & ${ }^{99 m} \mathrm{Tc}-\mathrm{IL}-2$ & Melanoma & C & Pilot Study \\
\hline $\begin{array}{c}\text { Renard V et al, } \\
2007 \text { [30] }\end{array}$ & Belgium & ${ }^{123}|-| L-2$ & $\begin{array}{c}\text { Renal } \\
\text { carcinoma }\end{array}$ & 0 & Pilot Study \\
\hline $\begin{array}{c}\text { Signore A et al, } \\
2004[31]\end{array}$ & Italy & 99mTc-IL2 & Melanoma & C & Pilot Study \\
\hline $\begin{array}{c}\text { Higashikawa K et al, } \\
2014 \text { [35] }\end{array}$ & Japan & ${ }^{64} \mathrm{Cu}$-DOTA-anti-CTLA & Colon cancer & $\mathrm{C}$ & $\begin{array}{c}\text { Not applicable } \\
\text { (Preclinical study) }\end{array}$ \\
\hline $\begin{array}{c}\text { Ehlerding EB et al, } \\
2017 \text { [24] }\end{array}$ & USA & $\begin{array}{l}{ }^{64} \mathrm{Cu} \text {-DOTA- } \\
\text { ipilimumab }\end{array}$ & Lung cancer & $\mathrm{C}$ & $\begin{array}{c}\text { Not applicable } \\
\text { (Preclinical study) }\end{array}$ \\
\hline $\begin{array}{c}\text { Natarajan A et al, } \\
2017 \text { [25] }\end{array}$ & USA & ${ }^{89} \mathrm{Zr}$-pembrolizumab & Melanoma & C & $\begin{array}{c}\text { Not Applicable } \\
\text { (Preclinical study) }\end{array}$ \\
\hline $\begin{array}{c}\text { Natarajan A et al, } \\
2018 \text { [26] }\end{array}$ & USA & ${ }^{64} \mathrm{Cu}$-pembrolizumab & Melanoma & $\mathrm{C}$ & $\begin{array}{c}\text { Not Applicable } \\
\text { (Preclinical study) }\end{array}$ \\
\hline $\begin{array}{l}\text { Jagoda EM et al, } \\
2019 \text { [27] }\end{array}$ & USA & ${ }^{89} \mathrm{Zr}$-Df-nivolumab & Lung cancer & C & $\begin{array}{c}\text { Not Applicable } \\
\text { (Preclinical study) }\end{array}$ \\
\hline
\end{tabular}

$\mathrm{H}$ : Hospital discharge registry; C: Cancer registry; O: Other. 
Table 2. Selected ongoing trials with TME radiopharmaceuticals in cancer patients treated with ICls

\begin{tabular}{|c|c|c|c|c|c|}
\hline Radiopharmaceutical & $\begin{array}{c}\text { Condition or } \\
\text { disease }\end{array}$ & Study Title & Phase & Status & $\begin{array}{c}\text { Clinicaltrials.gov } \\
\text { identifier }\end{array}$ \\
\hline${ }^{89} \mathrm{Zr}$-Atezolizumab & $\begin{array}{c}\text { Lobular } \\
\text { metastatic } \\
\text { breast cancer }\end{array}$ & $\begin{array}{c}{ }^{89} \mathrm{Zr} \text {-atezolizumab PET scan } \\
\text { and lobular breast cancer } \\
\text { (ImaGelato) }\end{array}$ & $\begin{array}{c}\text { Not } \\
\text { Applicable }\end{array}$ & Recruiting & NCT04222426 \\
\hline${ }^{89} \mathrm{Zr}$-Atezolizumab & $\begin{array}{l}\text { Lobular } \\
\text { diffuse large } \\
\text { B-cell } \\
\text { lymphoma, } \\
\text { not otherwise } \\
\text { specified }\end{array}$ & $\begin{array}{l}\text { Molecular imaging using } \\
\text { radiolabeled atezolizumab } \\
\text { to assess atezolizumab } \\
\text { biodistribution in } \\
\text { lymphoma patients }\end{array}$ & $\begin{array}{c}\text { Not } \\
\text { Applicable }\end{array}$ & Recruiting & NCT03850028 \\
\hline${ }^{89} \mathrm{Zr}$-Ipilimumab & Melanoma & $\begin{array}{c}\text { Uptake and biodistribution } \\
\text { of }{ }^{89} \mathrm{Zr} \text {-labeled ipilimumab } \\
\text { in ipilimumab treated } \\
\text { patients with metastatic } \\
\text { melanoma }\end{array}$ & II & Recruiting & NCT03313323 \\
\hline $\begin{array}{l}{ }^{99 m} \text { Tc-anti-PD- } \\
\text { L1( }{ }^{99 m} \text { Tc-NM-01) }\end{array}$ & $\begin{array}{l}\text { Non small cell } \\
\text { lung cancer }\end{array}$ & $\begin{array}{l}\text { 99m Tc labeled anti-PD-L1 } \\
\text { sdAb SPECT/CT in } \\
\text { assessment of PD-L1 } \\
\text { expression in NSCLC }\end{array}$ & I & Recruiting & NCT02978196 \\
\hline $\begin{array}{c}{ }^{18} \mathrm{~F}-\mathrm{PD}-\mathrm{L} 1\left(\left[{ }^{18} \mathrm{~F}\right] \mathrm{BMS}-\right. \\
986192)\end{array}$ & $\begin{array}{l}\text { Advanced non } \\
\text { small cell lung } \\
\text { cancer }\end{array}$ & $\begin{array}{l}{ }^{18} \mathrm{~F}-\mathrm{PD}-\mathrm{L} 1 \mathrm{PET} / \mathrm{CT} \text { in } \\
\text { nivolumab treated } \\
\text { patients with NSCLC }\end{array}$ & $\begin{array}{c}\text { Not } \\
\text { Applicable }\end{array}$ & Recruiting & NCT03564197 \\
\hline 99mTc-IL2 & $\begin{array}{l}\text { Stage IV skin } \\
\text { melanoma }\end{array}$ & $\begin{array}{l}\text { Aldesleukin Imaging in } \\
\text { viewing tumor growth in } \\
\text { patients with stage IV } \\
\text { melanoma receiving } \\
\text { ipilimumab or } \\
\text { pembrolizumab therapy }\end{array}$ & I & Completed & NCT01789827 \\
\hline${ }^{18} \mathrm{~F}-\mathrm{IL} 2\left(\left[{ }^{18} \mathrm{~F}\right] \mathrm{FB}-\mathrm{IL} 2\right)$ & Melanoma & $\begin{array}{l}\text { IL2 imaging in metastatic } \\
\text { melanoma }\end{array}$ & $\begin{array}{c}\text { Not } \\
\text { Applicable }\end{array}$ & Terminated & NCT02922283 \\
\hline${ }^{18} \mathrm{~F}-\mathrm{IL} 2\left(\left[{ }^{18} \mathrm{~F}\right] \mathrm{FB}-\mathrm{IL} 2\right)$ & Melanoma & $\begin{array}{l}{ }^{18} \mathrm{~F} \text {-FLT PET imaging in } \\
\text { patients with advanced } \\
\text { melanoma }\end{array}$ & 1 & Terminated & NCT02891616 \\
\hline${ }^{68} \mathrm{Ga}$-NOTA-GZP & $\begin{array}{l}\text { Non small cell } \\
\text { lung cancer, } \\
\text { melanoma }\end{array}$ & $\begin{array}{l}\text { Granzyme B PET imaging } \\
\text { drug as a predictor of } \\
\text { immunotherapy response } \\
\text { in melanoma or NSCLC } \\
\text { participants }\end{array}$ & I & $\begin{array}{l}\text { Not yet } \\
\text { recruiting }\end{array}$ & NCT04169321 \\
\hline
\end{tabular}


Table 3. Tumor microenvironment analysis with radiopharmaceuticals

\begin{tabular}{|c|c|c|c|c|c|c|c|}
\hline $\begin{array}{c}\text { TME } \\
\text { target }\end{array}$ & $\begin{array}{l}\text { Type of } \\
\text { study }\end{array}$ & Radiopharmaceutical & Cancer type & Setting & $\begin{array}{c}\mathrm{N}^{\circ} \text { of } \\
\text { patients }\end{array}$ & Comment & Ref \\
\hline $\begin{array}{l}\text { Tumor } \\
\text { cells }\end{array}$ & CAIX & ${ }^{111}$ In-girentuximab & $\begin{array}{l}\text { Clear cell } \\
\text { renal } \\
\text { carcinoma }\end{array}$ & Human & 29 & $\begin{array}{l}\text { Detecting ccRCC } \\
\text { lesions }\end{array}$ & [13] \\
\hline $\begin{array}{l}\text { Tumor } \\
\text { cells }\end{array}$ & CAIX & ${ }^{111}$ In-girentuximab & $\begin{array}{l}\text { Clear cell } \\
\text { renal } \\
\text { carcinoma }\end{array}$ & Human & 16 & $\begin{array}{l}\text { Early detection of } \\
\text { residual or recurrent } \\
\text { disease after } \\
\text { cryoablation }\end{array}$ & [14] \\
\hline $\begin{array}{l}\text { Tumor } \\
\text { cells }\end{array}$ & CAIX & ${ }^{111}$ In-girentuximab & $\begin{array}{l}\text { Head\&Neck } \\
\text { carcinoma }\end{array}$ & $\begin{array}{l}\text { In-vitro } \\
\text { and in-vivo } \\
\text { (mice) }\end{array}$ & - & $\begin{array}{l}\text { A promising tracer } \\
\text { for imaging of } \\
\text { hypoxia-related CAIX } \\
\text { expression }\end{array}$ & [15] \\
\hline $\begin{array}{l}\text { Tumor } \\
\text { cells }\end{array}$ & CAIX & ${ }^{111}$ In-girentuximab & $\begin{array}{l}\text { Clear cell } \\
\text { renal } \\
\text { carcinoma }\end{array}$ & Human & 15 & $\begin{array}{l}\text { Sorafenib reduced } \\
\text { the uptake of }{ }^{111} \mathrm{In}- \\
\text { girentumab in CRCC } \\
\text { lesions. Results } \\
\text { indicate that TKI } \\
\text { could interfered with } \\
\text { the efficacy of } \\
\text { antibody-mediated } \\
\text { treatment }\end{array}$ & {$[16]$} \\
\hline $\begin{array}{l}\text { Tumor } \\
\text { cells }\end{array}$ & CAIX & ${ }^{177}$ Lu-girentuximab & $\begin{array}{l}\text { Renal cell } \\
\text { carcinoma }\end{array}$ & $\begin{array}{l}\text { In-vitro } \\
\text { and in-vivo } \\
\text { (mice) }\end{array}$ & - & $\begin{array}{l}\text { Heterogeneous } \\
\text { expression of the } \\
\text { CAIX antigen and } \\
\text { necrosis resulted in } \\
\text { lower tumor uptake }\end{array}$ & [28] \\
\hline $\begin{array}{l}\text { Tumor } \\
\text { cells }\end{array}$ & PSMA & $\begin{array}{l}{ }^{111} \text { In-labeled D2B } \\
\text { IgG-DTPA, F(ab')2- } \\
\text { DTPA, Fab-DTPA, and } \\
\text { capromab-DTPA }\end{array}$ & $\begin{array}{l}\text { Prostate } \\
\text { cancer }\end{array}$ & Mice & $\begin{array}{l}4 \text { groups } \\
\text { of } 5 \text { mice }\end{array}$ & $\begin{array}{l}\text { Targeting PSMA- } \\
\text { expressing prostate } \\
\text { cancer xenografts }\end{array}$ & [17] \\
\hline $\begin{array}{l}\text { Tumor } \\
\text { cells }\end{array}$ & PDL1 & 111In-PD-L1.3.1 & $\begin{array}{l}\text { Breast } \\
\text { cancer }\end{array}$ & $\begin{array}{l}\text { In-vitro } \\
\text { and in-vivo } \\
\text { (mice) }\end{array}$ & $\begin{array}{l}7 \text { groups } \\
\text { of } 6 \text { mice }\end{array}$ & $\begin{array}{c}\text { Discriminates } \\
\text { xenografts with high } \\
\text { and low PD-L1 } \\
\text { expression levels }\end{array}$ & [18] \\
\hline $\begin{array}{l}\text { Tumor } \\
\text { cells }\end{array}$ & PDL1 & $\begin{array}{c}{ }^{89} \mathrm{Zr} \text {-DFO-PD-L1 } \\
\text { MoAb }\end{array}$ & $\begin{array}{c}\text { Breast, } \\
\text { gastric, lung } \\
\text { cancer }\end{array}$ & $\begin{array}{l}\text { In-vitro } \\
\text { and in-vivo } \\
\text { (mice) }\end{array}$ & - & $\begin{array}{c}\text { Uptake increased } \\
\text { with escalating dose } \\
\text { of avelumab }\end{array}$ & [20] \\
\hline $\begin{array}{l}\text { Tumor } \\
\text { cells }\end{array}$ & PDL1 & ${ }^{68} \mathrm{Ga}-\mathrm{DOTA}-\mathrm{Nb} 109$ & Melanoma & Mice & - & $\begin{array}{l}\text { Evaluating the PD-L1 } \\
\text { status and } \\
\text { the effect of immune } \\
\text { checkpoint targeting } \\
\text { treatment }\end{array}$ & [32] \\
\hline $\begin{array}{l}\text { Tumor } \\
\text { cells }\end{array}$ & EGFR & ${ }^{111}$ In-cetuximab & $\begin{array}{l}\text { Head\&Neck } \\
\text { squamous } \\
\text { cell } \\
\text { carcinoma }\end{array}$ & $\begin{array}{l}\text { In-vitro } \\
\text { and in-vivo } \\
\text { (mice) }\end{array}$ & $\begin{array}{l}7 \text { groups } \\
\text { of } 6 \text { mice }\end{array}$ & $\begin{array}{l}\text { Noninvasive imaging } \\
\text { of EGFR to select } \\
\text { patients for EGFR- } \\
\text { targeted therapy }\end{array}$ & [19] \\
\hline $\begin{array}{l}\text { Tumor } \\
\text { cells }\end{array}$ & EGFRvIII & ${ }^{125} \mid-4 G 1$ & Glioblastoma & $\begin{array}{l}\text { In-vitro } \\
\text { and in-vivo } \\
\text { (mice) }\end{array}$ & - & $\begin{array}{l}\text { 125I-4G1 had a high } \\
\text { tumor uptake in } \\
\text { EGFRvIll-positive } \\
\text { mice. It could be } \\
\text { valuable for the } \\
\text { diagnosis, prognosis } \\
\text { and evaluation of } \\
\text { therapeutic efficacy }\end{array}$ & [33] \\
\hline Tumor & IGF-1R & ${ }^{111}$ In- and ${ }^{225} A c-$ & TNBC & In-vitro & - & The efficacy of & [34] \\
\hline
\end{tabular}




\begin{tabular}{|c|c|c|c|c|c|c|c|}
\hline cells & & cixutumumab & & $\begin{array}{l}\text { and in-vivo } \\
\text { (mice) }\end{array}$ & & $\begin{array}{l}\text { cixutumumab can be } \\
\text { enhanced by } \\
\text { radiolabeling with } \\
{ }^{225} \mathrm{Ac} \text { at a low specific } \\
\text { activity }\end{array}$ & \\
\hline $\begin{array}{l}\text { Tumor } \\
\text { cells }\end{array}$ & B7-H3 & ${ }^{89} \mathrm{Zr}-\mathrm{DS}-5573 a$ & $\begin{array}{l}\text { Breast, colon } \\
\text { cancer }\end{array}$ & Mice & - & $\begin{array}{l}\text { Identify treatment } \\
\text { response and provide } \\
\text { important insights } \\
\text { into T cell biology }\end{array}$ & [21] \\
\hline PBMcs & $\mathrm{CD} 8$ & ${ }^{89} \mathrm{Zr}$-anti-CD8 & Melanoma & $\begin{array}{l}\text { Preclinical } \\
\text { syngeneic } \\
\text { tumor }\end{array}$ & - & $\begin{array}{l}\text { Evaluating change in } \\
\text { systemic CD8+ T-cells }\end{array}$ & [22] \\
\hline TILs & $\begin{array}{l}\text { IL2 } \\
\text { receptor }\end{array}$ & ${ }^{123}$ I-IL2 & $\begin{array}{l}\text { Head\&Neck } \\
\text { carcinoma }\end{array}$ & Human & 17 & $\begin{array}{l}\text { Non-invasive imaging } \\
\text { of the amount of IL2R } \\
\text { present on TILs }\end{array}$ & [29] \\
\hline TILs & $\begin{array}{l}\text { IL2 } \\
\text { receptor }\end{array}$ & 99mTc-IL2 & Melanoma & Human & 5 & $\begin{array}{c}\text { Safety and feasibility } \\
\text { of }{ }^{99 m} \text { TC-IL2 SPECT/CT } \\
\text { to examine TIL } \\
\text { changes and to } \\
\text { evaluate response to } \\
\text { ICls }\end{array}$ & [23] \\
\hline TILs & $\begin{array}{l}\text { IL2 } \\
\text { receptor }\end{array}$ & ${ }^{123}$ I-IL2 & $\begin{array}{l}\text { Renal cell } \\
\text { carcinoma }\end{array}$ & Human & 9 & $\begin{array}{l}\text { Identify cytokine } \\
\text { treatments response }\end{array}$ & [30] \\
\hline TILs & $\begin{array}{l}\text { IL2 } \\
\text { receptor }\end{array}$ & 99mTc-IL2 & Melanoma & Human & $\begin{array}{l}21 \\
\text { patients } \\
9 \\
\text { controls }\end{array}$ & $\begin{array}{l}\text { Prognostic role for } \\
\text { selecting patients } \\
\text { who might benefit of } \\
\text { IL2 immunotherapy }\end{array}$ & [31] \\
\hline TILs & CTLA4 & $\begin{array}{c}{ }^{64} \mathrm{Cu} \text {-DOTA-anti- } \\
\text { CTLA-4 }\end{array}$ & Colon cancer & Mice & - & $\begin{array}{l}\text { Evaluation of CTLA-4 } \\
\text { expression in tumor }\end{array}$ & [35] \\
\hline TILs & CTLA4 & $\begin{array}{l}{ }^{64} \mathrm{Cu}-\mathrm{DOTA}- \\
\text { ipilimumab }\end{array}$ & Lung cancer & $\begin{array}{l}\text { In-vitro } \\
\text { and in-vivo } \\
\text { (mice) }\end{array}$ & - & $\begin{array}{l}\text { Understanding ICls } \\
\text { and development of } \\
\text { future CTLA-4- } \\
\text { targeted treatments }\end{array}$ & [24] \\
\hline TILs & PD-1 & ${ }^{89} \mathrm{Zr}$-pembrolizumab & Melanoma & Mice & - & $\begin{array}{l}\text { Monitor cancer } \\
\text { response to ICls }\end{array}$ & [25] \\
\hline TILs & PD-1 & ${ }^{64} \mathrm{Cu}$-pembrolizumab & Melanoma & Mice & - & $\begin{array}{l}\text { Evaluation of PD-1 } \\
\text { receptor and } \\
\text { dosimetry prediction }\end{array}$ & [26] \\
\hline TILs & PD-1 & ${ }^{89} \mathrm{Zr}$-Df-nivolumab & Lung cancer & $\begin{array}{l}\text { In-vitro } \\
\text { and in-vivo } \\
\text { (mice) }\end{array}$ & - & $\begin{array}{c}\text { Evaluation of T-cells } \\
\text { expressing PD-1 }\end{array}$ & [27] \\
\hline
\end{tabular}

TM: Tumor microenvironment; CAIX: Carbonic anhydrase IX; PSMA: prostate-specific membrane antigen; EGFR: epidermal growth factor receptor; TKI: Tyrosine kinase inhibitors; EGFRvIll: Epidermal growth factor receptor mutant III; IGF-1R: Insulin growth factor receptor; TNBC: triple-negative breast cancer; PBMCs: peripheral blood mononuclear cells; TILs: tumor-infiltrating lymphocytes; ICls: immune checkpoint inhibitors. 


\section{References}

1. Signore A.; Lauri C.; Galli F. Radiolabelled probes targeting infection and inflammation for personalized medicine. Curr Pharm Des 2014, 20, 2338-45.

2. Signore A.; Lauri C.; Auletta S.; Varani M.; Onofrio L.; Glaudemans A.W.J.M.; Panzuto F.; Marchetti P. Radiopharmaceuticals for Breast Cancer and Neuroendocrine Tumors: Two Examples of How Tissue Characterization May Influence the Choice of Therapy. Cancers (Basel). 2020, 12(4), 781.

3. Galli F.; Casali M.; Versari A.; Glaudemans A.W.J.M. Immuno-Imaging to Predict Treatment Response in Infection, Inflammation and Oncology. J Clin Med. 2019, 8(5), 681.

4. Goubran H.A.; Kotb R.R.; Stakiw J.; Emara M.E. ; Burnouf T. Regulation of tumor growth and metastasis: the role of tumor microenvironment. Cancer Growth and Metastasis 2014,7, 9-18.

5. Joyce J.A.; Pollard J.W. Microenvironmental regulation of metastasis. Nature reviews: Cancer. 2009, 9(4), 239-252.

6. Hood J.D.; Cheresh D.A. Role of integrins in cell invasion and migration. Nat Rev Cancer 2002, 2, 91-100.

7. Baume D.M.; Robertson M.J; Levine H.; Manley T.J.; Schow P.W.; Ritz J. Differential responsens to interleukin 2 define functionally distinct subsets of human natural killer cells. Eur J Immunol 1992, 22, 1-6.

8. Renard V.; Staelens L.; Signore A.; Van Belle S.; Dierckx R.A.; Van De Wiele C. lodine-123-interleukin-2 scintigraphy in metastatic hypernephroma: a pilot study. Q J Nucl Med Mol Imaging 2007, 51, 352-6.

9. Signore A.; Annovazzi A.; Barone R.; Bonanno E.; D'Alessandria C.; Chianelli M.; Mather S.J.; Bottoni U.; Panetta C.; Innocenzi D.; Scopinaro F.; Calvieri S. 99mTc-interleukin-2 scintigraphy as a potential tool for evaluating tumor-infiltrating lymphocytes in melanoma lesions: a validation study. J Nucl Med 2004, 45, 1647-52.

10. Loose D.; Signore A.; Staelens L.; Bulcke K.V.; Vermeersch H.; Dierckx R.A. ; Bonanno E. ; Van de Wiele C. (123)I-Interleukin-2 uptake in squamous cell carcinoma of the head and neck carcinoma. Eur J Nucl Med Mol Imaging 2008, 35, 281-6.

11. Zappa C.; Mousa S.A. Non-small cell lung cancer: current treatment and future advances. Transl Lung Cancer Res. 2016, 5, 288-300.

12. Moher D.; Liberati A.; Tetzlaff J.; Altman D.G. PRISMA Group. Preferred reporting items for systematic reviews and meta-analyses: the PRISMA statement. BMJ. 2009, 339, b2535.

13. Muselaers C.H.; Boerman O.C.; Oosterwijk E.; Langenhuijsen J.F.; Oyen W.J.; Mulders P.F. Indium-111labeled girentuximab immunoSPECT as a diagnostic tool in clear cell renal cell carcinoma. Eur Urol. 2013, 63(6),1101-6.

14. van Oostenbrugge T.J.; Langenhuijsen J.F.; Oosterwijk E.; Boerman O.C.; Jenniskens S.F.; Oyen W.J.G.; Fütterer J.J.; Mulders P.F.A. Follow-up imaging after cryoablation of clear cell renal cell carcinoma is feasible using single photon emission computed tomography with $111 \mathrm{ln}$-girentuximab. Eur J Nucl Med Mol Imaging. 2020, 47(8),1864-1870.

15. Huizing F.J.; Hoeben B.A.W.; Franssen G.; Lok J.; Heskamp S.; Oosterwijk E.; Boerman O.C.; Bussink J. Preclinical validation of 111 In-girentuximab-F(ab')2 as a tracer to image hypoxia related marker CAIX expression in head and neck cancer xenografts. Radiother Oncol. 2017, 124(3), 521-525.

16. Muselaers C.H.; Stillebroer A.B.; Desar I.M.; Boers-Sonderen M.J.; van Herpen C.M.; de Weijert M.C.; Langenhuijsen J.F.; Oosterwijk E.; Leenders W.P.; Boerman O.C.; Mulders P.F.; Oyen W.J. Tyrosine kinase inhibitor sorafenib decreases 111 In-girentuximab uptake in patients with clear cell renal cell carcinoma. J Nucl Med. 2014, 55(2), 242-7.

17. Lütje S.; van Rij C.M.; Franssen G.M.; Fracasso G.; Helfrich W.; Eek A.; Oyen W.J.; Colombatti M.; Boerman O.C. Targeting human prostate cancer with 111/n-labeled D2B IgG, F(ab')2 and Fab fragments in nude mice with PSMA-expressing xenografts. Contrast Media Mol Imaging. 2015, 10(1), 28-36.

18. Heskamp S.; Hobo W.; Molkenboer-Kuenen J.D.; Olive D.; Oyen W.J. ; Dolstra H. ; Boerman O.C. Noninvasive Imaging of Tumor PD-L1 Expression Using Radiolabeled Anti-PD-L1 Antibodies. Cancer Res. 2015, 75(14), 2928-36.

19. Hoeben B.A.; Molkenboer-Kuenen J.D.; Oyen W.J.; Peeters W.J.; Kaanders J.H.; Bussink J. ; Boerman O.C. Radiolabeled cetuximab: dose optimization for epidermal growth factor receptor imaging in a head-and-neck squamous cell carcinoma model. Int J Cancer. 2011, 129(4), 870-8. 
20. Jagoda, E.M.; Vasalatiy, O.; Basuli, F.; Opina, A.C.L.; Williams, M.R.; Wong, K.; Lane, K.C.; Adler, S.; Ton, A.T.; Szajek, L.P.; et al. Immuno-PET Imaging of the Programmed Cell Death-1 Ligand (PD-L1) Using a Zirconium-89 Labeled Therapeutic Antibody, Avelumab. Mol. Imaging 2019, 18.

21. Burvenich I.J.G.; Parakh S.; Lee F.T.; Guo N.; Liu Z.; Gan H.K.; Rigopoulos A.; O'Keefe G.J.; Gong S.J.; Goh Y.W.; Tochon-Danguy H.; Scott F.E.; Kotsuma M.; Hirotani K.; Senaldi G.; Scott A.M. Molecular imaging of T cell coregulator factor B7-H3 with ${ }^{89} \mathrm{Zr}$-DS-5573a. Theranostics. 2018, 8(15), 4199-4209.

22. Tavaré R.; Escuin-Ordinas H.; Mok S.; McCracken M.N.; Zettlitz K.A.; Salazar F.B.; Witte O.N.; Ribas A.; Wu A.M. An Effective Immuno-PET Imaging Method to Monitor CD8-Dependent Responses to Immunotherapy. Cancer Res. 2016, 76(1), 73-82.

23. Markovic S.N.; Galli F.; Suman V.J.; Nevala W.K.; Paulsen A.M.; Hung J.C.; Gansen D.N.; Erickson L.A; Marchetti P.; Wiseman G.A.; Signore A. Non-invasive visualization of tumor infiltrating lymphocytes in patients with metastatic melanoma undergoing immune checkpoint inhibitor therapy: a pilot study. Oncotarget. 2018 Jul, 9(54), 3026830278.

24. Ehlerding E.B.; England C.G.; Majewski R.L.; Valdovinos H.F.; Jiang D.; Liu G.; McNeel D.G.; Nickles R.J.; Cai W. ImmunoPET Imaging of CTLA-4 Expression in Mouse Models of Non-small Cell Lung Cancer. Mol Pharm. 2017, 14(5), 1782-1789.

25. Natarajan A.; Mayer A.T.; Reeves R.E.; Nagamine C.M.; Gambhir S.S. Development of Novel ImmunoPET Tracers to Image Human PD-1 Checkpoint Expression on Tumor-Infiltrating Lymphocytes in a Humanized Mouse Model. Mol Imaging Biol. 2017, 19(6), 903-914.

26. Natarajan A.; Patel C.B.; Habte F.; Gambhir S.S. Dosimetry Prediction for Clinical Translation of ${ }^{64} \mathrm{Cu}-$ Pembrolizumab ImmunoPET Targeting Human PD-1 Expression. Sci Rep. 2018, 8(1), 633.

27. Jagoda E.M.; Vasalatiy O.; Basuli F.; Opina A.C.L.; Williams M.R.; Wong K.; Lane K.C.; Adler S.; Ton A.T.; Szajek L.P.; Xu B.; Butcher D.; Edmondson E.F.; Swenson R.E.; Greiner J.; Gulley J.; Eary J.; Choyke PL. Immuno-PET Imaging of the Programmed Cell Death-1 Ligand (PD-L1) Using a Zirconium-89 Labeled Therapeutic Antibody, Avelumab. Mol Imaging. 2019, 18, 1536012119829986.

28. Basaco T.; Pektor S.; Bermudez J.M.; Meneses N.; Heller M.; Galván J.A.; Boligán K.F.; Schürch S.; von Gunten S.; Türler A.; Miederer M. Evaluation of Radiolabeled Girentuximab In Vitro and In Vivo. Pharmaceuticals (Basel). 2018, 11(4), 132.

29. Loose D.; Signore A.; Staelens L.; Bulcke KV.; Vermeersch H.; Dierckx RA.; Bonanno E.; Van de Wiele C. (123)IInterleukin-2 uptake in squamous cell carcinoma of the head and neck carcinoma. Eur J Nucl Med Mol Imaging. 2008, 35(2), 281-6.

30. Renard V.; Staelens L.; Signore A.; Van Belle S.; Dierckx R.A; Van De Wiele C. lodine-123-interleukin-2 scintigraphy in metastatic hypernephroma: a pilot study. Q J Nucl Med Mol Imaging. 2007, 51(4), 352-6.

31. Signore A.; Annovazzi A.; Barone R.; Bonanno E.; D'Alessandria C.; Chianelli M.; Mather SJ.; Bottoni U.; Panetta C.; Innocenzi D.; Scopinaro F.; Calvieri S. 99mTc-interleukin-2 scintigraphy as a potential tool for evaluating tumorinfiltrating lymphocytes in melanoma lesions: a validation study. J Nucl Med. 2004, 45(10), 1647-52.

32. Lv G.; Sun X.; Qiu L.; Sun Y.; Li K.; Liu Q.; Zhao Q.; Qin S.; Lin J. PET Imaging of Tumor PD-L1 Expression with a Highly Specific Nonblocking Single-Domain Antibody. J Nucl Med. 2020, 61(1), 117-122.

33. Liu X.; Dong C.; Shi J.; Ma T.; Jin Z.; Jia B.; Liu Z.; Shen L.; Wang F. Radiolabeled novel mAb 4 G1 for immunoSPECT imaging of EGFRvIII expression in preclinical glioblastoma xenografts. Oncotarget. 2017, 8(4), 6364-6375.

34. Solomon V.R.; Alizadeh E.; Bernhard W.; Hartimath S.V; Hill W.; Chekol R.; Barreto K.M; Geyer C.R; Fonge H. ${ }^{111}$ Inand ${ }^{225} \mathrm{AC}$-Labeled Cixutumumab for Imaging and $\alpha$-Particle Radiotherapy of IGF-1R Positive Triple-Negative Breast Cancer. Mol Pharm. 2019, 16(12), 4807-4816.

35. Higashikawa K.; Yagi K.; Watanabe K.; Kamino S.; Ueda M.; Hiromura M.; Enomoto S. 64Cu-DOTA-anti-CTLA-4 mAb enabled PET visualization of CTLA-4 on the T-cell infiltrating tumor tissues. PLoS One. 2014, 9(11), e109866.

36. Evangelista L.; de Jong M.; del Vecchio S.; Cai W. The new era of cancer immunotherapy: what can molecular imaging do the help? Clin Transl Imaging 2017, 5, 299-301.

37. Zeelen C.; Paus C.; Draper D.; Heskamp S.; Signore A.; Galli F.; Griessinger CM.; Aarntzen EH. In-vivo imaging of tumor-infiltrating immune cells: implications for cancer immunotherapy. Q J Nucl Med Mol Imaging. 2018, 62(1), 56-77.

38. Natarajan A.; Mayer A-T.; Xu L.; Reeves R.E.; Gano J.; Gambhir S.S. Novel Radiotracer for ImmunoPET Imaging of PD-1 Checkpoint Expression on Tumor Infiltrating Lymphocytes. Bioconjug Chem 2015, 26, 2062-69. 